\title{
Ketoconazole- and Fluconazole-Induced Embryotoxicity and Skeletal Anomalies in Wistar Rats: A Comparative Study
}

\author{
Vanessa Cristiane de Santana Amaral ${ }^{1 *}$ and Guilhermino Pereira Nunes Junior ${ }^{2}$ \\ ${ }^{1}$ Unidade Universitária de Ciências Exatas e Tecnológicas ;Universidade Estadual de Goiás. ${ }^{2}$ Departamento de \\ Ciências Fisiológicas; Laboratório de Teratogênese Experimental; Universidade Federal de Goiás; \\ vanessa.cristiane@ueg.br; Goiânia-GO - Brasil
}

\begin{abstract}
Ketoconazole and fluconazole are two broad-spectrum azole antifungals used for the treatment of superficial and systemic mycoses. Embryotoxicity and teratogenicity have been reported in some studies when those drugs are administered at high doses to pregnant rats. The aim of this study was to present a comparative study of embryotoxic effects as well as the skeletal anomalies in fetuses of Wistar rats which received ketoconazole and fluconazole at teratogenic doses on gestational days (GD) 6 through 15 (organogenesis period). On gestational day (GD) 21, the dams were euthanized and examined for standard parameters of reproductive outcome. Fetuses were stained with alizarin red and the bones of the head, trunk, forelimb and hindlimb were examined for detection of skeletal anomalies. The frequency of skeletal anomalies in the ketoconazole-treated group was significant when compared to the fluconazole and the control group.
\end{abstract}

Key words: Ketoconazole, fluconazole, maternal toxicity, embryotoxicity, skeletal malformations

\section{INTRODUCTION}

During pregnancy, women are more susceptible to fungal infections (King et al., 1998). Studies have shown a higher prevalence of vulvovaginal candidiasis among pregnant than nonpregnant women and that this prevalence tends to increase as gestational age advances (Cotch et al., 1998). In addition to opportunistic mycoses as vulvovaginitis, systemic mycoses as cryptococcosis (Pereira et al., 1993; Chen and Wang, 1996; Ely et al., 1998) and coccidioidomycosis (Peterson et al., 1993) have been reported in pregnant women.

Ketoconazole, a broad-spectrum imidazole antifungal, has efficiently been used in the treatment of several superficial as well as systemic mycoses (Sheehan et al., 1999). However, studies have shown the teratogenic and embryotoxic potential of this drug when administered through gavage at higher doses in pregnant rats. Syndactyly and oligodactyly in fetuses have been reported after the administration of $80 \mathrm{mg} / \mathrm{kg}(10$ times the maximum recommended human dose) of ketoconazole in pregnant rats (Briggs et al., 1998). High incidence of fetal resorption as well as a significant number of stillbirths showing embryotoxicity and fetotoxicity has been revealed by another study using different doses $(10,25$ or $50 \mathrm{mg} / \mathrm{kg}$ ) of ketoconazole in pregnant rats on gestational days 6 through 21 (Buttar et al., 1989). There have been few data describing the use of this drug in human gestation (Lind, 1985; Amado et al., 1990; Berwaerts et al., 1999).

\footnotetext{
* Author for correspondence
} 
The use of fluconazole, a triazolic antifungal, during the gestation of animals and humans has been largely investigated. The administration of this drug at doses ranging from $80 \mathrm{mg} / \mathrm{kg}$ to 320 $\mathrm{mg} / \mathrm{kg}$ to pregnant rats $(20-60$ times the recommended human dose) resulted in embryolethality increased and fetal abnormalities, including wavy ribs, cleft palate, and abnormal craniofacial ossification (Tachibana et al., 1987; Pursley et al., 1996). Epidemiological studies and case reports showing controversial results have described the fluconazole effects on humans. Pursley et al. (1996) have reported cases in which three children were exposed to fluconazole taken by the mothers for the treatment of coccidioidomycosis at $400 \mathrm{mg}$ and $800 \mathrm{mg}$ daily during pregnancy. Abnormalities in the children such as brachycephaly, cleft palate, micrognathia, fracture of the femur, thin ribs, clavicles, and long bones, radiohumeral synostosis and others alike were reported. Only one of the fetuses survived. However, prospective study carried out with 226 women who received either $150 \mathrm{mg}$ of fluconazole as a single dose or $50 \mathrm{mg}$ or $150 \mathrm{mg}$ as multiple doses in the first trimester of gestation has not revealed fetal malformations (Mastroiacovo et al., 1996). In addition to results of studies on animals, such data suggested that teratogenicity of fluconazole might be dose-dependent.

Since there are no adequate and controlled studies in humans and also the studies on animals have shown the teratogenic potential of these drugs, ketoconazole and fluconazole are classified by the FDA as Pregnancy Category C; i.e., these drugs should be used during pregnancy only if the potential benefit justifies the potential risk to the fetus. Antifungal agents are extensively used in human medicine. Therefore, their reproductive toxicologic effects need to be ascertained both in terms of maternal exposure and reproductive outcome. This work aimed at presenting a comparative study of the embryotoxic effects as well as the skeletal anomalies in fetuses of Wistar rats, which received ketoconazole and fluconazole at doses of $80 \mathrm{mg} / \mathrm{kg} / \mathrm{day}$ and $100 \mathrm{mg} / \mathrm{kg} / \mathrm{day}$, respectively, during organogenesis.

\section{MATERIALS AND METHODS}

The approval for the use of animals and for the procedures required for the experiments was obtained by the Ethical Committee for Animals
Use in Experimental Studies of University of Goiás. Wistar rats maintained in polyethylene cages were used in this experiment only after a 15day acclimatization period. They were kept under a controlled temperature of $22 \pm 2^{\circ} \mathrm{C}$ and at defined light/dark cycle (light from 07:00 to 19:00 h). Twenty-nine nulliparous females ranging in weight $180-200 \mathrm{~g}$ were housed overnight with males of the same stock on the basis of one male to one female. Copulation was ascertained daily by vaginal smear or copulation plug. The day on which spermatozoa were found in a smear of vaginal contents or a copulation plug was observed in situ was designated as gestation day (GD) zero. The pregnant rats were housed individually. Body weight changes, food and water consumption were recorded from days 0 to 21 . The rectal temperature was taken on days $0,7,15$ and 21 of gestation. Animals were observed daily for survival and any reactions to treatment.

The study was composed of three groups randomly chosen. Group treatment $1 \quad(n=10)$ received ketoconazole at a dose of $80 \mathrm{mg} / \mathrm{kg}$, group treatment $2(\mathrm{n}=9)$ received fluconazole at a dose of $100 \mathrm{mg} / \mathrm{kg}$ and the control group $(\mathrm{n}=10)$ received equal volume of isotonic saline vehicle $(4 \mathrm{~mL} / \mathrm{kg})$. The compounds were administered once daily by gavage on GD 6-15, i.e., during organogenesis.

On day 21 of gestation, the females were submitted to euthanasia and their ovaries were removed by cesarean section and the number of corpora lutea in each ovary was recorded. The fetuses were removed from the uterus and examined to determine both the number of live and dead fetuses and macroscopic abnormalities. The fetuses and the placentas were weighed individually. Early and late resorptions as well as the number of implantation sites were recorded. Resorption was classified "early" when only placental tissue was visible and "late" when placenta as well as embryonic tissue was visible. Fetuses were cleared with $\mathrm{KOH}$ and stained with alizarin red (Manson et al., 1982; Effting et al., 2004) and examined under a dissecting microscope. Skeletal anomalies were analyzed according to a modified method of Manson et al. (1982). The number of ossified metacarpals, metatarsals, distal and proximal phalanges was obtained by taking the sum of bones present in both paws in each of the fetuses. The $14^{\text {th }}$ thoracic ribs were evaluated according to Kimmel and Wilson (1973) and separated into groups as follows: rudimentary ribs if less than half the 
length of the $13^{\text {th }}$ thoracic rib and supernumerary if half or greater than half the length of the preceding $13^{\text {th }}$ rib.

Both maternal data and the variables of reproductive outcome were analyzed by ANOVA followed by Tukey-Kramer's multiple comparison test. Skeletal anomalies were analyzed by Fisher's exact test and chi-square test. Statistical significance was assumed at $P<0.05$.

\section{RESULTS}

\section{Maternal effects}

Clinical observations showed a higher tolerance to fluconazole than to ketoconazole by pregnant rats. Vaginal bleeding was noted in two dams, which received ketoconazole. In one of them the bleeding occurred on days 13 and 14 while in the other the same happened on the 20 and 21 days of gestation. Diarrhea was noted in most of animals treated with ketoconazole. No behavioral alteration was observed on dams in all groups. The results of maternal toxicity of dams treated with saline, ketoconazole and fluconazole are shown in Table 1. The mean food consumption by the ketoconazole group during organogenesis was significantly decreased when compared with the control and the fluconazole group. Nevertheless, there were no statistically significant differences in mean food consumption by both the control and fluconazole groups in all periods of gestation. No statistically significant difference in mean rectal temperature was noted in ketoconazole and fluconazole groups when compared with the control group.

\section{Reproductive outcome}

Reproductive outcome data are summarized in Table 2. A statistically significant increase both in the mean percentages of postimplantation loss and in the number of both early and late postimplantation resorptions was observed in ketoconazole group when compared with fluconazole and control group. Additionally, a significant increase in the mean number of implantation sites as well as a decrease in the mean of fetal body weights per litter was observed in the ketoconazole group when compared with the control group, but not when compared with fluconazole group. It was interesting to note that the number of implantation sites was not treatment related, since dosing began on GD 6, after implantation. The mean placental weight was increased in both ketoconazole and fluconazole groups when compared with control group.

\section{External fetal anomalies}

There were no anomalies in any of the fetuses in the control group. Syndactyly was found in three $(5.88 \%)$ fetuses from the same litter of ketoconazole group. A single case of spina bifida was found in the fluconazole group.

\section{Axial skeletal anomalies}

A total of 72 fetuses of control group, 51 fetuses of ketoconazole group and 64 fetuses of fluconazole group were observed for skeletal anomalies. There were no significant cranial anomalies in control group and fluconazole group (Table 3). Frontal, parietal and interparietal incomplete ossification was observed in ketoconazole group. Moreover, cleft palate was observed in 31 fetuses of the same group. Those anomalies were considered statistically significant when compared with control group. There was a remarkable reduction in the percentage of the same cranial anomalies in the fluconazole group when compared with ketoconazole group.

Skeletal anomalies in the trunk are described in Table 4 . The analysis of the sternum revealed that more than half of the fetuses in the ketoconazole group showed a complete ossification of six sternebrae, whereas 16 fetuses in the same group had only five ossified sternebrae on the $21^{\text {st }}$ gestational day. Similarly to the ketoconazole group, about $69 \%$ of the fetuses in fluconazole group had six sternebrae.

Skeletal alterations such as supernumerary and rudimentary ribs, either unilateral or bilateral, were observed in fetuses of all groups. Supernumerary $14^{\text {th }}$ ribs were significantly increased in ketoconazole and fluconazole groups when compared with control group. Nevertheless, supernumerary $14^{\text {th }}$ ribs were significantly increased in ketoconazole group when compared with fluconazole group (Table 4). Rudimentary $7^{\text {th }}$ ribs were also significantly increased in both the ketoconazole and fluconazole groups when compared with control group. The skeletal analysis also revealed the occurrence of rudimentary $14^{\text {th }}$ ribs in all groups, although in the fluconazole group the number of fetuses with this anomaly was significantly increased when compared with ketoconazole group. In addition, the rudimentary 
$15^{\text {th }}$ ribs were found only in the ketoconazole group (Table 4).

\section{Apendicular skeletal anomalies}

The data regarding to forelimb and hindlimb anomalies are shown in Tables 5 and 6, respectively. A significant decrease in the ossified metacarpals and metatarsals in both paws was found in the fetuses of ketoconazole group when compared with the fetuses of fluconazole and control groups. Among the fetuses of ketoconazole group, only 11 had 8 ossified metacarpals (Table 5) and 10 of them had 10 ossified metatarsals (Table 6).

The total of ossified metacarpals and metatarsals of fluconazole group was statistically different from ketoconazole group, although it was similar to the control group. A significant decrease in the number of ossified distal phalanges in several fetuses of ketoconazole group was found. In almost forty of those fetuses, distal phalanges were absent. In the fluconazole group, in turn, approximately $1 / 3$ of the fetuses showed a significant increase in the number of those phalanges when compared with the fetuses of control and ketoconazole groups (Table 5). Proximal phalanges were absent in $98.04 \%$ of fetuses of ketoconazole group and $75 \%$ of fluconazole group (Table 6).

No skeletal anomalies were found in the radius, ulna and humerus in the fetuses of all groups. Significant skeletal anomalies of hindlimbs were found in ketoconazole group; fibula and pubis were absent and femur, tibia and pubis were shortened. Such anomalies were not found in both fluconazole and control groups (Table 6).

Table 1 - Weight gain, food consumption, water intake, and rectal temperature of female Wistar rats treated with saline, ketoconazole and fluconazole by gavage during organogenesis.

\begin{tabular}{|c|c|c|c|}
\hline \multirow{2}{*}{ Parameter } & \multicolumn{3}{|c|}{ Treatment } \\
\hline & Saline 4 mL/kg & Ketoconazole 80 mg/kg & Fluconazole 100 mg/kg \\
\hline Number of dams/group & 10 & 10 & 09 \\
\hline \multicolumn{4}{|l|}{ Weight gain $(\mathrm{g})$} \\
\hline \multicolumn{4}{|l|}{ Days } \\
\hline $0-5$ & $17.4 \pm 1.5$ & $18.1 \pm 2.1$ & $12.2 \pm 1.3$ \\
\hline $6-15$ & $24.9 \pm 1.7$ & $16.1 \pm 3.8$ & $26.6 \pm 2.9$ \\
\hline $16-21$ & $45.9 \pm 4.6$ & $34.5 \pm 8.2$ & $45.5 \pm 4.8$ \\
\hline \multicolumn{4}{|l|}{ Food intake $(\mathrm{g})$} \\
\hline \multicolumn{4}{|l|}{ Days } \\
\hline $0-5$ & $16.7 \pm 0.4$ & $16.8 \pm 0.6$ & $17.7 \pm 0.4$ \\
\hline $6-15$ & $18.1 \pm 0.7$ & $15.5 \pm 0.7 *$ & $18.2 \pm 0.4 \dagger$ \\
\hline $16-21$ & $21.3 \pm 0.9$ & $19.9 \pm 1.2$ & $20.1 \pm 0.9$ \\
\hline \multicolumn{4}{|l|}{ Water intake (mL) } \\
\hline \multicolumn{4}{|l|}{ Days } \\
\hline $0-5$ & $36.6 \pm 1.3$ & $39.5 \pm 1.7$ & $35.0 \pm 1.2$ \\
\hline $6-15$ & $43.6 \pm 3.1$ & $41.4 \pm 1.7$ & $41.2 \pm 1.0$ \\
\hline $16-21$ & $48.5 \pm 3.5$ & $50.2 \pm 3.2$ & $44.8 \pm 1.5$ \\
\hline Rectal temperature $\left({ }^{\circ} \mathrm{C}\right)^{\mathrm{a}}$ & $37.3 \pm 0.1$ & $37.5 \pm 0.1$ & $37.3 \pm 0.1$ \\
\hline
\end{tabular}


Table 2 - Reproductive outcome of female Wistar rats treated with saline, ketoconazole and fluconazole during organogenesis.

\begin{tabular}{|c|c|c|c|}
\hline \multirow[b]{2}{*}{ Parameters } & \multicolumn{3}{|c|}{ Treatment } \\
\hline & $\begin{array}{c}\text { saline } \\
4 \mathrm{~mL} / \mathrm{kg}\end{array}$ & $\begin{array}{c}\text { ketoconazole } \\
80 \mathrm{mg} / \mathrm{kg} \\
\end{array}$ & $\begin{array}{c}\text { fluconazole } \\
100 \mathrm{mg} / \mathrm{kg}\end{array}$ \\
\hline Number of corpora lutea ${ }^{c}$ & $12.1 \pm 0.8$ & $12.3 \pm 0.4$ & $11.4 \pm 0.5$ \\
\hline Number of implantation sites ${ }^{c}$ & $7.5 \pm 1.1$ & $11.1 \pm 0.8 *$ & $8.4 \pm 0.9$ \\
\hline Number of preimplantation resorptions ${ }^{c}$ & $4.6 \pm 1.1$ & $1.2 \pm 0.6$ & $2.9 \pm 1.0$ \\
\hline Preimplantation loss $(\%)^{\mathrm{ac}}$ & $36.6 \pm 9.1$ & $9.8 \pm 5.4$ & $24.7 \pm 9.1$ \\
\hline Postimplantation loss $(\%)^{\mathrm{bc}}$ & $3.2 \pm 2.3$ & $51.9 \pm 8.6 *$ & $21.5 \pm 11.0 \dagger$ \\
\hline Number of postimplantation resorptions ${ }^{c}$ & $0.3 \pm 0.2$ & $5.9 \pm 1.1 *$ & $1.4 \pm 0.6 \dagger$ \\
\hline Number of early resorptions ${ }^{c}$ & $0.3 \pm 0.2$ & $5.0 \pm 1.2 *$ & $1.4 \pm 0.6 \dagger$ \\
\hline Number of late resorptions ${ }^{c}$ & 0 & $0.9 \pm 0.3 *$ & $0 \dagger$ \\
\hline Total number of fetuses ${ }^{c}$ & $7.2 \pm 1.0$ & $5.2 \pm 0.9$ & $7.1 \pm 1.0$ \\
\hline Number of dead fetuses ${ }^{c}$ & 0 & $0.1 \pm 0.1$ & $0.1 \pm 0.1$ \\
\hline Number of live fetuses ${ }^{c}$ & $7.2 \pm 1.0$ & $5.1 \pm 1.0$ & $7.0 \pm 1.1$ \\
\hline Placental weight $(\mathrm{g})^{\mathrm{c}}$ & $0.63 \pm 0.02$ & $0.98 \pm 0.06 *$ & $1.05 \pm 0.07 *$ \\
\hline Fetal weight $(g)^{c}$ & $5.02 \pm 0.18$ & $4.14 \pm 0.22 *$ & $4.81 \pm 0.33$ \\
\hline
\end{tabular}

Table 3 - Craniofacial anomalies of fetuses from dams treated with saline, ketoconazole and fluconazole during organogenesis.

\begin{tabular}{|c|c|c|c|}
\hline \multirow[b]{2}{*}{ Anomaly } & \multicolumn{3}{|c|}{ Treatment } \\
\hline & $\begin{array}{c}\text { saline } \\
4 \mathrm{~mL} / \mathrm{kg}\end{array}$ & $\begin{array}{l}\text { ketoconazole } \\
80 \mathrm{mg} / \mathrm{kg}\end{array}$ & $\begin{array}{c}\text { fluconazole } \\
100 \mathrm{mg} / \mathrm{kg}\end{array}$ \\
\hline Total number of fetuses & 72 & 51 & 64 \\
\hline Frontal incomplete ossification & $0(0)$ & $7(13,73)^{*}$ & $0(0) \dagger$ \\
\hline Parietal incomplete ossification & $0(0)$ & $21(41,18)^{*}$ & $1(1,56) \dagger$ \\
\hline Interparietal incomplete ossification & $0(0)$ & $6(11,76)^{*}$ & $0(0) \dagger$ \\
\hline Supraoccipital incomplete ossification & $1(1,39)$ & $0(0)$ & $0(0)$ \\
\hline Absent frontal & $0(0)$ & $0(0)$ & $1(1,56)$ \\
\hline Absent interparietal & $0(0)$ & $0(0)$ & $1(1,56)$ \\
\hline Absent temporal & $0(0)$ & $0(0)$ & $1(1,56)$ \\
\hline Absent left tympanic ring & $0(0)$ & $3(5,88)$ & $0(0)$ \\
\hline Absent tympanic ring (both sides) & $0(0)$ & $0(0)$ & $1(1,56)$ \\
\hline Cleft palate & $0(0)$ & $31(60,78)^{*}$ & $0(0) \dagger$ \\
\hline
\end{tabular}

Values represent number of fetuses affected. Numbers in parentheses represent the percentage of fetuses affected. $* P<0.05$ when compared with saline group, $\dagger P<0.05$ when compared with ketoconazole group.

$\left(\chi^{2}\right.$ followed by Fisher's exact test). 
Table 4 - Trunk skeletal anomalies of fetuses from dams treated with saline, ketoconazole and fluconazole during organogenesis.

\begin{tabular}{|c|c|c|c|}
\hline \multirow[b]{2}{*}{ Anomaly } & \multicolumn{3}{|c|}{ Treatment } \\
\hline & $\begin{array}{c}\text { saline } \\
4 \mathrm{~mL} / \mathrm{kg}\end{array}$ & $\begin{array}{c}\text { ketoconazole } \\
80 \mathrm{mg} / \mathrm{kg}\end{array}$ & $\begin{array}{c}\text { fluconazole } \\
100 \mathrm{mg} / \mathrm{kg}\end{array}$ \\
\hline Total number of fetuses & 72 & 51 & 64 \\
\hline \multicolumn{4}{|l|}{ Sternum } \\
\hline Six ossified sternebrae & $61(84,72)$ & $32(62,75)^{*}$ & $44(68,75)^{*}$ \\
\hline Five ossified sternebrae & $9(12,50)$ & $16(31,37)^{*}$ & $19(29,69)^{*}$ \\
\hline Four ossified sternebrae & $2(2,78)$ & $3(5,88)$ & $0(0)$ \\
\hline Two ossified sternebrae & $0(0)$ & $0(0)$ & $1(1,56)$ \\
\hline \multicolumn{4}{|l|}{ Supernumerary $14^{\text {th }}$ ribs } \\
\hline Left side & $5(6,94)$ & $39(76,47)^{*}$ & $25(39,06)^{* \dagger}$ \\
\hline Right side & $6(8,33)$ & $33(64,71)^{*}$ & $24(37,50) * \dagger$ \\
\hline \multicolumn{4}{|l|}{ Rudimentary $7^{\text {th }}$ ribs } \\
\hline Left side & $0(0)$ & $19(37,25)^{*}$ & $32(50,00)^{*}$ \\
\hline Right side & $0(0)$ & $19(37,25)^{*}$ & $32(50,00)^{*}$ \\
\hline \multicolumn{4}{|l|}{ Rudimentary $14^{\text {th }}$ ribs } \\
\hline Left side & $32(44,44)$ & $11(21,57)^{*}$ & $39(60,94) \dagger$ \\
\hline Right side & $26(36,11)$ & $17(33,33)$ & $40(62,50)^{* \dagger}$ \\
\hline \multicolumn{4}{|l|}{ Rudimentary $15^{\text {th }}$ ribs } \\
\hline Left side & $0(0)$ & $6(11,76)^{*}$ & $0(0) \dagger$ \\
\hline Right side & $0(0)$ & $7(13,73)^{*}$ & $0(0) \dagger$ \\
\hline
\end{tabular}

Values represent number of fetuses affected. Numbers in parentheses represent the percentage of fetuses affected.

$* P<0.05$ when compared with saline group, $\dagger P<0.05$ when compared with ketoconazole group.

$\left(\chi^{2}\right.$ followed by Fisher's exact test).

Table 5 - Forelimb skeletal anomalies of fetuses from dams treated with saline, ketoconazole and fluconazole during organogenesis.

\begin{tabular}{|c|c|c|c|}
\hline \multirow[b]{2}{*}{ Anomaly } & \multicolumn{3}{|c|}{ Treatment } \\
\hline & $\begin{array}{c}\text { saline } \\
4 \mathrm{~mL} / \mathrm{kg}\end{array}$ & $\begin{array}{l}\text { ketoconazole } \\
80 \mathrm{mg} / \mathrm{kg}\end{array}$ & $\begin{array}{c}\text { fluconazole } \\
100 \mathrm{mg} / \mathrm{kg}\end{array}$ \\
\hline Total number of fetuses & 72 & 51 & 64 \\
\hline \multicolumn{4}{|l|}{ Number of ossified metacarpals } \\
\hline 8 & $67(93,05)$ & $11(21,57)^{*}$ & $59(92,18) \dagger$ \\
\hline 7 & $4(5,56)$ & $0(0)$ & $3(4,69)$ \\
\hline 6 & $1(1,39)$ & $31(60,78)^{*}$ & $2(3,13) \dagger$ \\
\hline 5 & $0(0)$ & $1(1,96)$ & $0(0)$ \\
\hline 4 & $0(0)$ & $3(5,88)$ & $0(0)$ \\
\hline 2 & $0(0)$ & $5(9,81)^{*}$ & $0(0) \dagger$ \\
\hline \multicolumn{4}{|l|}{ Number of ossified phalanges } \\
\hline 8 & $10(13,89)$ & $0(0)^{*}$ & $21(32,81)^{* \dagger}$ \\
\hline 7 & $2(2,78)$ & $0(0)$ & $1(1,56)$ \\
\hline 6 & $15(20,83)$ & $0(0)^{*}$ & $12(18,75) \dagger$ \\
\hline 4 & $22(30,56)$ & $5(9,81)^{*}$ & $25(39,07) \dagger$ \\
\hline 3 & $5(6,94)$ & $1(1,96)$ & $1(1,56)$ \\
\hline 2 & $3(4,17)$ & $4(7,84)$ & $1(1,56)$ \\
\hline 1 & $1(1,39)$ & $1(1,96)$ & $0(0)$ \\
\hline 0 (zero) & $14(19,44)$ & $40(78,43)^{*}$ & $3(4,69) * \dagger$ \\
\hline
\end{tabular}

Values represent number of fetuses affected. Numbers in parentheses represent the percentage of fetuses affected.

$* P<0.05$ when compared with saline group, $\uparrow P<0.05$ when compared with ketoconazole group.

$\left(\chi^{2}\right.$ followed by Fisher's exact test). 
Table 6 - Hindlimb skeletal anomalies of fetuses from dams treated with saline, ketoconazole and fluconazole during organogenesis.

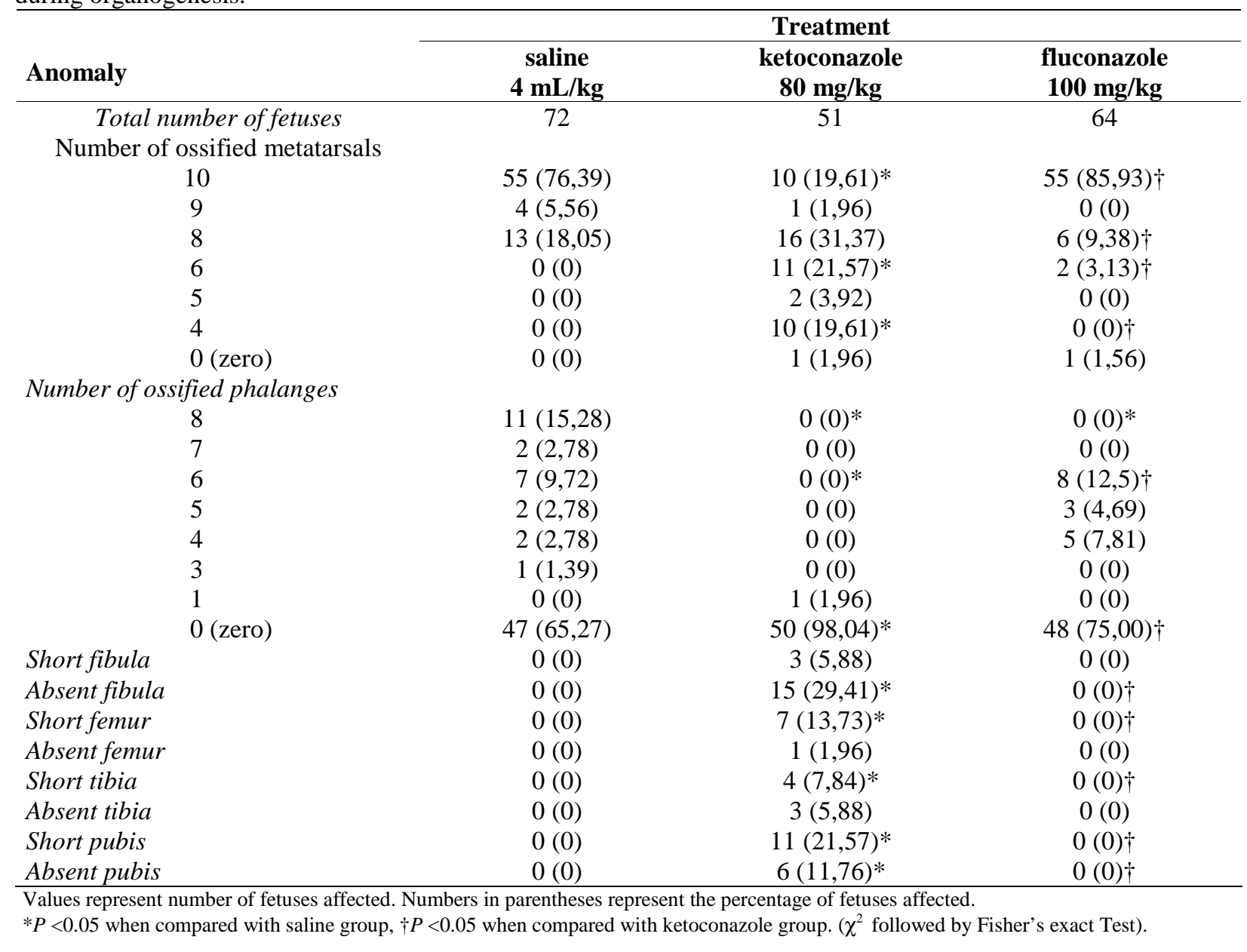

\section{DISCUSSION}

The results of the present study showed that ketoconazole at a dose of $80 \mathrm{mg} / \mathrm{kg} / \mathrm{day}$ administered during organogenesis led Wistar rats to a significant decrease in food consumption as well as to the appearance of clinical signs of toxicity (diarrhea and vaginal bleeding). Maternal toxicity is characterized by a decrease in weight gain, decrease in food and water consumption, clinical signs, certain organ toxicity, and mortality (Chahoud et al., 1999). Thus, in this study maternal toxicity as well as the subsequent fetuses anomalies could be regarded as a result of ketoconazole treatment.

Embryotoxicity is known to be a result of high prevalence of reabsorptions, fetal death and fetal body weight reduction (Khera, 1984). Reproductive outcome analysis demonstrated that the only treatment with ketoconazole caused significant alterations in the parameters indicating embryotoxicity when compared with control group. Thus, the embryotoxicity induced by ketoconazole during gestation could be related either to physiological or maternal homeostasis alterations, which showed the possibility that fetal effects observed, could be secondary to maternal toxicity.

Fetal skeletal analysis revealed a higher prevalence of anomalies in fetuses of ketoconazole group when compared with fluconazole and control group. It was interesting to note that cleft palate, bones shortened or even absent in hindlimbs in Wistar rats treated with ketoconazole at a dose of $80 \mathrm{mg} / \mathrm{kg}$ during organogenesis had not been described before. As there has been evidence of inhibition of mammalian steroidogenesis induced by ketoconazole and also due to a lack of affinity for fungal P-450 enzymes (Eckhoff et al., 1988; Dudley, 1990), the data of 
this study suggested that the impairment both in gestation and fetal skeletal development in ketoconazole group could be a consequence of inhibition of maternal steroidogenesis. Similarly, those effects were weakly marked in fluconazole group due to a higher affinity for fungal P-450 enzymes by this antifungal drug (Eckhoff et al., 1988; Dudley, 1990).

Some aspects regarding the presence of supernumerary and rudimentary ribs in fetuses of all groups must be taken into consideration. Such fetal alterations in all groups could be regarded as variations rather than malformations in the skeletal development of the litters, since some of these variations appeared to be strain-specific, and therefore, could show different magnitudes of response in other species (Kimmel and Wilson, 1973).

These results suggested that the administration of fluconazole in pregnant rats appeared to be safer than that ketoconazole. Nevertheless, it must be pointed out that accurate evaluation by the clinicians should be done in order to assure whether potential benefits of fluconazole use by pregnant women justified the possible risks to the fetus.

\section{ACKNOWLEDGMENTS}

The authors are grateful to Fundação de Apoio à Pesquisa - FUNAPE for supporting this work and to Ms. Mara Victor for her assistance in the preparation of the manuscript. The authors also thank Janssen Cilag Pharmaceutica (São PauloBrazil) and Pfizer Laboratories (São Paulo-Brazil) for generously providing ketoconazole and fluconazole, respectively for this study.

\section{RESUMO}

O cetoconazol e o fluconazol são dois antifúngicos azólicos, de amplo espectro, utilizados no tratamento de micoses superficiais e sistêmicas. Alguns estudos relatam a embriotoxicidade e teratogenicidade induzidas por estes fármacos quando os mesmos são administrados em altas doses a ratas prenhes. O objetivo deste trabalho foi apresentar um estudo comparativo dos efeitos embriotóxicos e das anomalias esqueléticas em fetos de ratas Wistar que receberam cetoconazol e fluconazol em doses teratogênicas do $6^{\circ}$ ao $15^{\circ}$ dia gestacional (GD) (período da organogênese). No $21^{\circ} \mathrm{GD}$ as ratas foram eutanaziadas e examinadas quanto aos parâmetros padrões de performance reprodutiva. Os fetos foram corados com vermelho de alizarina e os ossos da cabeça, do tronco e dos membros anteriores e posteriores foram examinados para a verificação de anomalias esqueléticas. A frequiência de anomalias esqueléticas no grupo tratado com cetoconazol foi significante quando comparada à dos grupos fluconazol e controle.

\section{REFERENCES}

Amado, J.A.; Pesquera, C.; Gonzalez, E.M.; Otero, M.; Freijanes, J. and Alvarez, A. (1990), Successful treatment with ketoconazole of Cushing's syndrome in pregnancy. Postgrad. Med. J., 66, 221-223.

Berwaerts, J.; Verhelst, J.; Mahler, C. and Abs, R. (1999), Cushing's syndrome in pregnancy treated by ketoconazole: case report and review of the literature. Gynecol. Endocrinol., 13, 175-182.

Briggs, G.G.; Freeman, R.K. and Yaffe, S.J. (1998), Drugs in pregnancy and lactation: a reference guide to fetal and neonatal risk. U.S.A.: Lippincott Williams and Wilkins.

Buttar, H.S.; Moffatt, J.H. and Bura, C. (1989), Pregnancy outcome in ketoconazole-treated rats and mice. Teratology, 39, 444.

Chahoud, I.; Ligensa, A.; Dietzel, L. and Faqi, A.S. (1999), Correlation between maternal toxicity and embryo/fetal effects. Reprod. Toxicol., 13, 375-381.

Chen, C.P. and Wang, K.G. (1996), Cryptococcal meningitis in pregnancy. Amer. J. Perinatol., 13, 3536.

Cotch, M.F.; Hillier, S.L.; Gibbs, R.S. and Eschenbach, D.A. (1998), Epidemiology and outcomes associated with moderate to heavy Candida colonization during pregnancy. Am. J. Obstet. Gynecol., 178, 374-380.

Dudley, M.N. (1990), Clinical pharmacology of fluconazole. Pharmacotherapy, 10, 141-145.

Eckhoff, C.; Oelkers, W. and Bahr, V. (1988), Effects of two oral antimycotics, ketoconazole and fluconazole, upon steroidogenesis in rat adrenal cells in vitro. J. Steroid Biochem., 31, 819-823.

Effting, C.; De Paula, D.J. and Nunes Junior, G.P. (2004), A Model for the Study of Skeletal Anomalies in Rat Fetuses. Braz. arch. biol. technol., 47, 33-39.

Ely, E.W.; Peacock Jr, J.E.; Haponik, E.F. and Washburn, R.G. (1998), Cryptococcal pneumonia complicating pregnancy. Medicine, 77, 153-167.

Khera, K.S. (1984), Maternal toxicity - a possible factor in fetal malformations in mice. Teratology, 29, 411-416. 
Kimmel, C.A. and Wilson, J.G. (1973), Skeletal deviations in rats: malformations or variations? Teratology, 8, 309-316.

King, C.T.; Rogers, P.D.; Cleary, J.D. and Chapman, S.W. (1998), Antifungal therapy during pregnancy. Clin. Infect. Dis., 27, 1151-1160.

Lind J. (1985), Limb malformations in a case of hydrops fetalis with ketoconazole use during pregnancy. Arch. Gynecol., 237, 398.

Manson, J.M.; Zenick, H. and Costlow, R.D. (1982), Teratology test methods for laboratory animals. In: Principles and Methods of Toxicology. New York: Wallace Hayes, 141-184.

Mastroiacovo, P.; Mazzone, T.; Botto, L.D.; Serafini, M.A.; Finardi, A.; Caramelli, L. and Fusco, D. (1996), Prospective assessment of pregnancy outcomes after first trimester exposure to fluconazole. Am. J. Obstet. Gynecol., 175, 1645-1650.

Pereira, C.A.; Fischman, O.; Colombo, A.L.; Moron, A.F. and Pignatari, A.C. (1993), Neurocriptococose durante a gravidez. Rev. Inst. Med. Trop. S. Paulo, 35, 367-371.
Peterson, C.M.; Schuppert, K.; Kelly, P.C. and Pappagianis, D. (1993), Coccidioidomycosis and pregnancy. Obstet. Gynecol. Surv., 48, 149-156.

Pursley, T.J.; Blomquist, I.K.; Abraham, J.; Andersen, H.F. and Bartley, J.A. (1996), Fluconazole induced congenital anomalies in three infants. Clin. Infect. Dis., 22, 336-340.

Sheehan, D.J.; Hitchcock, C.A. and Sibley, C.M. (1999), Current and emerging azole antifungal agents. Clin. Microbiol. Rev., 12, 40-79.

Tachibana, M.; Noguchi, Y. and Monro, A.M. (1987), Toxicology of fluconazole in experimental animals. In: Fromtling, R.A. Recent trends in the discovery, development, and evaluation of antifungal agents. ed. JR Prous, Barcelona. pp.93-102.
Received: Janeiro 12, 2006; Revised: November 01, 2007; Accepted: July 04, 2008. 
PÁGINA

EM

BRANCO 